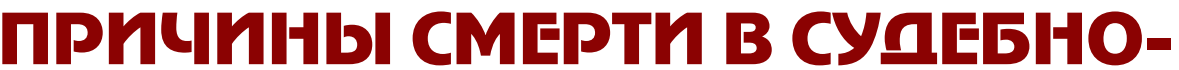 MEGRUИHCKOM OHAГHOBE
}

\author{
А.м.Н., проф. В.А. Клевно, к.м.н. О.В. Лысенко
}

Бюро судебно-медицинской экспертизы Московской области (нач. - д.м.н., проф. В.А.Клевно)

Аннотация: Статья посвящена причинам смерти в судебно-медицинском диагнозе. Проанализированы ключевые условия систематизации причин смерти при формулировании СМД, среди которых врач - судебномедицинский эксперт обязан выделить основную и непосредственную. Основной причиной смерти является нозологическая единица, оформленная в соответствии с требованиями МКБ-10, а непосредственной причиной смерти - осложнение основного заболевания (повреждения).

Ключевые слова: причины смерти, судебно-медицинский диагноз

\section{CAUSES OF DEATH IN THE FORENSIC DIAGNOSIS}

\section{V.A. Klevno, O.V. Lysenko}

Abstract: Key terms of systematization of death causes in the formulation of SMD were analyzed. A doctor, forensic expert, should identify the basic and direct cause. The main cause of death is nosological unit, designed in accordance with the ICD-10, and the direct cause of death is a complication of the underlying disease (damage).

Keywords: causes of death, forensic diagnosis

http://dx.doi.org/10.19048/2411-8729-2015-1-4-21-23

В настоящей статье речь пойдет, прежде всего, о причинах смерти при механических повреждениях, как наиболее часто встречаемых при судебно-медицинской экспертизе трупов в случаях смерти от различных ее видов; от действия некоторых физических факторов; расстройства здоровья и смерти от острого кислородного голодания, также вследствие отравлений.

При судебно-медицинской экспертизе трупа вопрос об установлении причины смерти является первостепенным. И от того, насколько полно, всесторонне и объективно проведено исследование, зависит качество заключения эксперта и обоснованность ответов на другие вопросы дознавателя, следователя, судьи.

Анализу и систематике причин смерти в судебномедицинской практике посвящено немало работ отечественных ученых (В.Н. Крюков, Б.А. Саркисян, В.Э. Янковский и др. 2003; В.Н. Крюков, И.В. Буромский, В.А. Клевно и др., 2014; В.А. Клевно, В.В. Хохлов, 2014; В.А. Клевно, С.А. Кучук, О.В. Лысенко и др., 2015).

По мере накопления медицинских знаний в области диагностики заболеваний, травм и отравлений, деятельность врача - судебно-медицинского эксперта при формулировании и построении СМД с выделением основной и непосредственной причин смерти требует от него не только переосмысления имеющегося практического опыта, но и получения новых специальных медицинских знаний, необходимых для точного установления причин смерти.

При формулировании СМД, судебно-медицинский эксперт обязан выделить основную и непосредственную причины смерти. Основной причиной смерти является нозологическая единица, оформленная в соответствии с требованиями МКБ- 10 , а непосредственной причиной смерти - осложнение основного заболевания (повреждения). Ключевым условием систематизации причин смерти является временной промежуток, прошедший от времени воздействия повреждающего фактора до времени наступления смерти.

Если смерть наступает тотчас после причинения травматического воздействия, без развития осложнений, которые могли привести к наступлению смерти, то в таком случае сама травма (повреждение) является одновременно основной и непосредственной причиной смерти, что должно найти свое отражении при формулировке и составлении СМД, а также при заполнении МСС.

Если смерть наступила в короткий либо отдаленный промежутки времени после причинения травматического воздействия с последующим развитием осложнений, которые привели к наступлению смерти, то в таком случае сама травма (повреждение) является основной, а осложнение - непосредственной причинами смерти, что должно найти свое отражении при формулировке и составлении СМД и заполнении МСС.

Традиционно принято выделять три группы причин смерти:

1) травма как основная и непосредственная причина смерти;

2) ближайшие осложнения травмы как непосредственная причина смерти;

3) отдаленные осложнения травмы как непосредственная причина смерти.

Однако при длительном нахождении пострадавших в стационаре последние зачастую переживают саму травму и связанные с ней ближайшие и отдаленные осложнения. Смерть таких пострадавших наступает от осложнений, явившихся следствием предыдущих осложнений. Такого рода осложнения названы нами осложнениями второго порядка, которые являются непосредственными причинами смерти.

Это положение дает нам веское основание продолжить традиционный перечень причин смерти, выделив в отдельную, иетвертую группу непосредственных причин смерти - осложнения второго порядка.

Теоретическое обобщение данных литературы и имеющегося практического опыта, позволяет нам дополнить сложившийся перечень причин смерти новой группой осложнений. Для простоты и наглядности восприятия основной и непосредственных причин смерти они сведены в общую таблицу.

Как следует из таблицы, традиционный перечень причин смерти, состоящий из трех групп, дополнен IV группой непосредственных причин смерти в виде осложнений второго порядка.

Наиболее типичным осложнением второго порядка является синдром диссеминированного внутрисосудистого свертывания (ДВС-синдром). 
Основные и непосредственные причины смерти

Таблица

\begin{tabular}{|c|c|}
\hline \multicolumn{2}{|r|}{$\begin{array}{c}\text { I группа } \\
\text { Травма как основная и непосредственная причина смерти }\end{array}$} \\
\hline 1. & Повреждения, несовместимые с жизнью \\
\hline 1.1. & Грубые нарушения анатомической целости тела, органов и тканей человека: \\
\hline 1.1.1. & Разделение тела на части. \\
\hline 1.1.2. & Отделение части тела (головы, туловища, конечностей). \\
\hline 1.1.3. & $\begin{array}{l}\text { Размозжение, отрыв, разрыв внутреннего органа (головного и спинного мозга, сердца, легких, печени, } \\
\text { других жизненно важных органов). }\end{array}$ \\
\hline 1.2. & Тупая травма рефлексогенных зон \\
\hline 1.3. & Ушиб (контузия) сердца \\
\hline 1.4 . & $\begin{array}{l}\text { Смерть от кислородного голодания, действия крайних температур, атмосферного давления, тех- } \\
\text { нического и атмосферного электричества, вследствие отравлений (напр., механическая асфиксия, } \\
\text { общее переохлаждение организма, баротравма, поражение техническим электричеством, отравление } \\
\text { алкоголем и др.) без развития осложнений. }\end{array}$ \\
\hline \multicolumn{2}{|r|}{$\begin{array}{c}\text { II группа } \\
\text { Ближайшие осложнения травмы как непосредственная причина смерти }\end{array}$} \\
\hline 1. & $\begin{array}{l}\text { Кровопотеря: } \\
\text { - острая; } \\
\text { • обильная (массивная). }\end{array}$ \\
\hline 2. & Травматический шок \\
\hline 3. & $\begin{array}{l}\text { Эмболия: } \\
\text { • жировая; } \\
\text { • воздушная; } \\
\text { • газовая; } \\
\text { • тромбоэмболия. }\end{array}$ \\
\hline 4. & $\begin{array}{l}\text { Сдавление жизненно важного органа: } \\
\text { - сдавление и дислокация головного мозга; } \\
\text { - сдавление спинного мозга. }\end{array}$ \\
\hline 5. & $\begin{array}{l}\text { Травматический гемоперикард: } \\
\text { • гемотампонада сердечной сорочки. }\end{array}$ \\
\hline 6. & Гемопневмоторакс \\
\hline 7. & Аспирация крови \\
\hline \multicolumn{2}{|r|}{$\begin{array}{c}\text { III группа } \\
\text { Отдаленные осложнения травмы как непосредственная причина смерти }\end{array}$} \\
\hline 1. & $\begin{array}{l}\text { Перитонит: } \\
\text { • разлитой (диффузный, общий). }\end{array}$ \\
\hline 2. & Посттравматическая пневмония \\
\hline 3. & Сепсис \\
\hline 4. & $\begin{array}{l}\text { Краш-синдром (травматический токсикоз или синдром длительного раздавливания), синдром позици- } \\
\text { онного сдавления. }\end{array}$ \\
\hline \multicolumn{2}{|r|}{$\begin{array}{c}\text { IV группа } \\
\text { Осложнения второго порядка как непосредственная причина смерти }\end{array}$} \\
\hline 1. & Диссеминированное внутрисосудистое свертывание (ДВС-синдром) \\
\hline 2. & $\begin{array}{l}\text { Другие осложнения второго порядка } \\
\text { • острая почечная недостаточность; } \\
\text { • острые язвы желудочно-кишечного тракта; } \\
\text { • вторичные кровотечения; } \\
\text { • истощение организма. }\end{array}$ \\
\hline
\end{tabular}


В случае обильной (массивной) кровопотери, гнойных осложнений может развиться тромбогеморрагический синдром или синдром диссеминированного внутрисосудистого свертьввания крови, обусловленный сочетанием замедленного кровотока в капиллярах с увеличенным содержанием прокоагулянтов в крови (3.С. Баркаган, 1988).

В развитии ДВС-синдрома выделяют четыре стадии.

I стадия (гиперкоагуляции) - характеризуется генерализованной активацией процесса свертывания и агрегации клеток (при хроническом течении процесса она сохраняется длительное время благодаря компенсаторным механизмам антикоагулянтной системы, срыв последних обусловливает переход его во вторую стадию);

II стадия (нарастающая коагулопатия потребления) - проявляется уменьшением количества тромбоцитов и фибриногена вследствие их убыли (потребления) на образование тромбов, расход плазменных факторов коагуляции;

III стадия (выраженной гипокоагуляции) - характеризуется формированием растворимых комплексов фибрин-мономеров, обладающих резистентностью к тромбину; патогенез этой стадии связан с несколькими факторами;

IV стадия - обратное развитие ДВС-синдрома.

Для установления причины смерти имеет значение III стадия ДВС-синдрома, которая является критической, нередко заканчивается летальным исходом.

Другие осложнения второго порядка как непосредственные причины смерти являются следствием либо кровопотери, либо эмболии, либо сепсиса. Таковыми являются острая почечная недостаточность, острые язвы желудочно-кишечного тракта, вторичные кровотечения, истощение организма.

Учитывая изложенное, мы рекомендуем врачу судебно-медицинскому эксперту при составлении СМД и заполнении МСС использовать термины и определения основных и непосредственных причин смерти, приведенных в настоящей таблице. Это будет способствовать повышению качества проведения экспертного исследования в части его полноты, всесторонности и объективности, что позволит специалисту в своем заключении дать обоснованные ответы на вопросы дознавателя, следователя и судьи.

\section{$\checkmark$ ЛИТЕРАТУРА}

1. Баркаган 3.С. Геморрагические заболевания и синдромы. - М., Медицина,1988. - 528 с.

2. Диагностикум причин смерти при механических повреждениях. Т. 7: Причины смерти при механических повреждениях / Крюков В.Н., Саркисян Б.А., Янковский В.Э. и др. - Новосибирск: Наука, 2003.- $131 \mathrm{c}$

3. Клевно В.А., Хохлов В.В. Судебная медицина: учебник для вузов / В. А. Клевно, В. В. Хохлов. - М.: Издательство Юрайт, 2014.- 520 с.: ил. - Серия: Бакалавр. Базовый курс.

4. Крюков В.Н., Буромский И.В., Клевно В.А. и др. Руководство по судебной медицине / под ред. В.Н. Крюкова, И.В. Буромского - М.: Норма: ИНФРА-М, 2014.- 656 с.: ил.

5. Судебно-медицинский диагноз: руководство. / [Клевно В.А., Кучук С.А., Лысенко О.В. и др.]; под ред. проф. В.А. Клевно - М.: Ассоциация СМЭ, 2015. - 340 с.: ил.

Для корреспонденции

КЛЕВНО Владимир Александрович - начальник государственного бюджетного учреждения Московской области «Бюро судебно-медицинской экспертизы» (ГБУЗ МО «Бюро СМЭ»), доктор медицинских наук, профессор. Адрес: 111401, г. Москва, ул. 1-я Владимирская, д. 33, корп. 1, ГБУЗ МО «Бюро СМЭ» • E- mail: vladimir.klevno@yandex.ru

ЛЫСЕНКО Олег Викторович - врач судебно-медицинский эксперт организационно-методического отдела государственного бюджетного учреждения Московской области «Бюро судебно-медицинской экспертизы» (ГБУЗ МО «Бюро СМЭ»), кандидат медицинских наук. Адрес: 111401, г. Москва, ул. 1-я Владимирская, д. 33, корп. 1, ГБУ3 МО «Бюро СМЭ»•E-mail: ovllun@mail.ru 